\title{
Straumhvörf í rannsóknum á fjölhæfum stofnfrumum og notagildi peirra í læknavísindum
}

\author{
Guðrún Valdimarsdóttir, Anne Richter
}

\section{ÁGRIP}

Stofnfrumur úr fósturvísum eru einangrađar úr fósturvísum eins og nafnið bendir til. Petta eru fjölhæfar frumur sem geta annaðhvort endurnýjast og haldist ósérhæfðar eđa sérhæfst í hvaða frumugerð sem er í líkamanum. Árið 1998 tókst að einangra stofnfrumur úr fósturvísum manna og breytti pað sýn manna á nýja möguleika í vefjalæknisfræði. Aðeins 8 árum síðar tókst vísindafólki að mynda svokallaðar iPS-frumur, fjölhæfar stofnfrumur sem útbúnar voru með pví að endurforrita líkamsfrumur. Petta hefur gjör- bylt hugmyndum um óafturkræfi frumuproska. Í kjölfarið hefur mikið verk verið unnið til pess að kryfja til mergjar sameindalíffræði fjölhæfra stofnfrumna. Unnt er að mynda iPS-frumur úr líkamsfrumum sjúklinga og hafa pær pví sama genamengi. Pessar frumur eru pví einstaklega nytsamar á ýmsum sviðum læknisfræðinnar og má meðal annars nýta pær til að skilja sjúkdómsframvindu, framkvæma lyfjaprófanir og vefjaígræðslur.
Fyrirspurnir: Guðrún Valdimarsdóttir gudrunva@hi.is

Greinin barst 1. apríl 2015 , sampykkt til birtingar 29. október 2015

Höfundar hafa útfyllt eyðublað um hagsmunatengsl.

\section{Stofnfrumur úr fósturvísum manna - hES-frumur}

Stofnfrumur hafa tvenns konar eiginleika: við frumuskiptingu geta pær annaðhvort endurnýjað sig eða sérhæfst í aðra frumugerð. Stofnfrumur úr fósturvísum (ES-frumur, embryonic stem cells) eru einangraðar úr fósturvísum. Pær eru fengnar úr glasafrjóvgunum með upplýstu sampykki aðstandenda og peim hefði annars átt að farga. ${ }^{1}$ Pær teljast fjölhæfar (pluripotent) pví pær geta sérhæfst í hvaða frumugerð líkamans sem er, ólíkt vefjasértækum stofnfrumum (tissue specific stem cells) sem geta aðeins sérhæfst í tiltekna frumugerð í vefnum sem pær finnast í, og eru pví kallaðar marghæfar (multipotent). ${ }^{2}$ Í gegnum tíðina hafa stofnfrumur úr fósturvísum verið ranglega nefndar fósturstofnfrumur. Í fóstri eru engar fjölhæfar stofnfrumur heldur aðeins vefjasértækar stofnfrumur. Margir renna hýru auga til ES-frumna sem úrræðis til lækninga á ýmsum sjúkdómum, par sem hægt verður að sérhæfa pær í ákveðnar frumugerðir sem sjúklingar purfa á að halda, og væri pá hægt að koma peim frumum fyrir í sjúklingnum. Sá böggull fylgir pó skammrifi að vefjaflokkaprótein eru tjáð í ES-frumunum og gæti pað orsakað höfnun frumnanna við ígræðslu. ${ }^{3}$

\section{Fósturproskun mannsins}

Okfruma myndast við samruna eggs og sáðfrumu. Hún skiptir sér á fyrstu stigum fósturproska og verður að hneppifóstri (morula) á 16. frumustigi. Kímblaðran (blastocyst) myndast svo á 4-5 degi og innheldur hún innri frumumassa (inner cell mass) umlukinn ytra lagi af næringarhýði (trophectoderm) sem síðar proskast í utanfósturvefi, svo sem fylgjuna. Innri frumumassinn myndar kímpekju (epiblast) sem við myndun holfósturs (gastrulation) á 14. degi proskast í fósturlögin prjú, innlag, miðlag og útlag. Eitt af aðalsmerkjum holfóstursmyndunar er myndun frumrákarinnar og sérhæfing hinna priggja fósturlaga. ${ }^{1}$ Fjölgun og frumuskrið kímpekjufruma fer fram í ferli sem kallast bandvefsumbreyting pekjuvefjar (Epithelial-to-mesenchymal transition, EMT) en pá minnkar viðloðun milli frumna og tenginga peirra við grunnhimnu og frumuskrið á sér stað. ES-frumur manna (hES-frumur) ganga einnig í gegnum EMT pegar pær sérhæfast í rækt. Við upphaf sérhæfingar eykst tjáning á EMT-stjórnpróteinum, svo sem SNAIL, SLUG og TWIST, en tjáning á viðloðunarpróteininu E-CADHERIN pverr.-6

Ef ytra lagið er varlega skilið frá innri frumumassa á kímblöðrustigi og frumum innri frumumassans sáð á ræktunarskálar við rétt skilyrði pá vaxa upp frumur í eyjum (kóloníum) sem nefnast stofnfrumur úr fósturvísum (mynd 1). Langt er síðan pví var spáð að hægt yrði að einangra hES-frumur. Proskunarfræðingar höfðu rannsakað furðuæxli (teratocarcinoma) sem finnast í eista og legi og innihalda misleita vefjablöndu, svo sem hár, vöðva, bein og tennur. Proskunarfræðingar fundu út að ef peir fjarlægðu fósturvísa úr legi og sprautuðu peim undir skinn á músum fóru að vaxa furðuæxli. Peir uppgötvuðu líka að pessi æxli innihéldu ósérhæfðar stofnfrumur sem gátu sérhæfst í ólíkar frumugerðir háð umhverfinu og kölluðu pær EC-frumur (embryonal carcinoma). Рað má pví segja að stofnfrumurannsóknir hafa notið góðs af peirri gríðarlegu pekkingu sem áunnist hafði með EC-frumunum. Árið 1981 tókst að einangra stofnfrumur úr fósturvísum músa ${ }^{7,8}$ en pað var ekki 


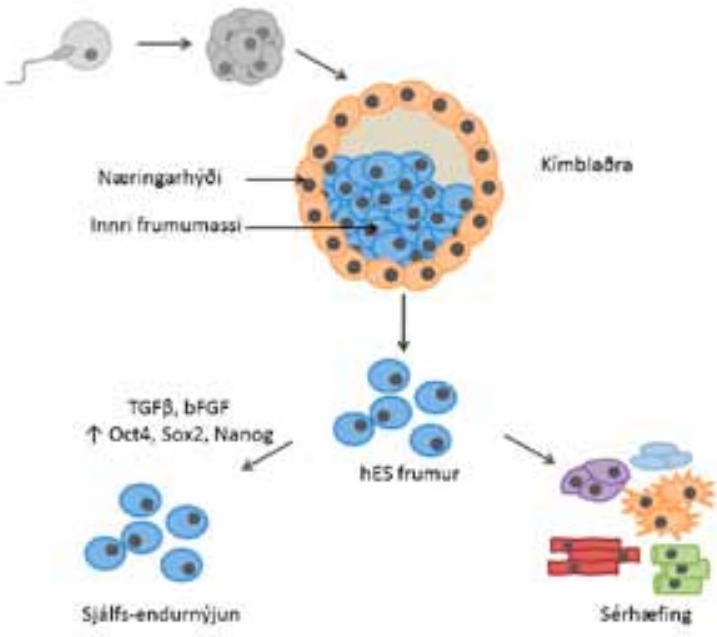

Mynd 1. Yfirlitsmynd af einangrun stofnfrumna úr fósturvísum manna. Kímblaðran myndast á 5. degi eftir frjóvgun eggs. Frumur næringarhýdis umlykja innri frumumassann sem verður að kímpekju og síðar einstaklingi ef kímblaðran nær að taka sér bólfestu í legi. Ef innri frumumassinn er einangraður og frumurnar ræktaðar við réttar aðstæður vaxa pær í eyjum, eru fjölhæfar og nefnast stofnfrumur úr fósturvísum (hES-frumur). Dá er annaðhvort hægt að halda peim fjölhæfum eða sérhæfa pær i ákveðna frumugerð.

fyrr en $1995^{9}$ sem tókst að einangra slíkar frumur úr prímötum og premur árum síðar úr mönnum. ${ }^{10}$ Af augljósum ástæðum er ekki hægt að sannreyna svipgerð hES-frumna með pví að búa til blendingsfóstur (chimeras) eins og mögulegt er í músum. Kenniprótein (markers) sem próuð voru til að rannsaka EC-frumur reyndust pví vel til að athuga ósérhæfðu hES-frumurnar. Skilgreining á hESfrumum byggist á prennu: hES-frumur eru ódauðlegar pví pær hafa telomerasa-virkni, hES-frumur tjá sértæk stjórnprótein og sértæk kenniprótein á yfirborði sínu, og hES-frumur mynda afleiður allra kímlaganna in vitro og furðuæxli in vivo.

\section{Aðferðir við stofnfrumurannsóknir}

hES-frumur viðhalda fjölhæfi sínu pegar pær eru ræktaðar á geisluðum eða mitomycin-C meðhöndluðum MEF-hjálparfrumum (mouse embryonic fibroblasts). MEF-frumurnar geta pví ekki skipt sér en seyta pó lífsnauðsynlegum páttum og eru fótfesta fyrir stofnfrumurnar sem vaxa upp í eyjum. Á seinustu árum hefur komið í ljós að vaxtarpættirnir sem MEF-frumurnar seyta og halda hES-frumunum ósérhæfðum eru einkum bFGF (basic Fibroblast Growth Factor) og TGF-beta (Transforming Growth Factor beta). ${ }^{11,12}$ Peir stuðla að tjáningu á stjórnpróteininu NANOG ${ }^{13}$ en heiti pessa próteins er myndað af orðunum Tír na nÓg sem pýðir land hinna ódauðlegu í keltneskum goðsögnum. ${ }^{14}$ NANOG ýtir undir tjáningu á OCT4 og SOX2 próteinunum en pessir prír stjórnpættir eru aðalstjórnpættir hES-frumna og mynda eins konar hringrás hvað varðar stjórnun peirra sín á milli (mynd 1). ${ }^{15,16} \mathrm{hES}$-frumum er vanalega umsáð með trypsíni eða svokallaðri cut-and paste-umsáningu og pær fluttar yfir á ferskt MEF-undirlag í ræktunarskálum. Sérhæfingu hES-frumna er einkum komið af stað með myndun frumuklasa (aggregates) sem í kjölfarið mynda frumukúlur (embryoid bodies) í fjarveru bFGF og TGF-beta. Pessar frumukúlur eru misleit blanda af alls kyns frumugerðum. Petta kallast tilviljanakennd sérhæfing (spontaneous differentiation) ${ }^{17}$ en pó má beina sérhæfingu hES-frumna í tilteknar áttir með vaxtarpáttum eða hindrum (directed differentiation). Sem dæmi má nefna að hES-frumur sem eru örvaðar með FGF8, Sonic Hedgehog (SHH) og WNT-boðleiðinni en boðflutningur um TGF-beta og BMP (Bone Morphogenetic Protein) um leið hindraður, sérhæfast í dópamínmyndandi taugafrumur. Petta hefur verið gert og frumum sem til verða sprautað í heila ungra músa með Parkinsonsjúkdóminn með árangri sem lofar góðu. ${ }^{18-20}$ Örvun með bFGF og BMP4 (undirflokkur TGFbetafjölskyldunnar) leiðir til sérhæfingar í miðlagsfrumum sem svo er hægt að sérhæfa frekar í hjarta- og æðafrumur eða blóðmyndandi stofnfrumur.,21 Ýmis dýralíkön eru notuð til að athuga öryggi, heimtur og starfhæfi pessara sérhæfðu frumna. Mýs, rottur og svín hafa til dæmis verið notuð til pess að græða hjartavöðvafrumur sem pannig voru búnar til í óstarfhæft hjarta eftir að hjartadrep var framkallað með pví að binda fyrir kransæðarnar. ${ }^{22-24}$

Stuttu eftir að tókst að einangra stofnfrumur úr fósturvísum manna komu í ljós ýmis vandamál sem upp gætu komið í stofnfrumulækningum. Tryggja parf að hES-frumurnar séu algerlega sérhæfðar í viðkomandi frumugerð, pví ef hES-frumunum sjálfum væri sprautað í sjúkling gætu pær myndað furðuæxli. Í upphafi krafðist ræktun hES-frumna einnig MEF-hjálparfrumna auk kálfasermis og var pá hætta á veirumengun og jafnvel kúariðusmiti. Pessum ótta hefur verið eytt með pví að sleppa MEF-hjálparfrumum og nota sermisfrítt æti. Ennfremur tjá hES-frumur vefjaflokkaprótein (HLA) á yfirborði sínu eftir sérhæfingu og leiðir pað til mögulegrar höfnunar sjúklings á pessum frumum við ígræðslu. ${ }^{3}$ Ein lausn á pessu var að nota klónun, pað er fjarlægja kjarna úr eggfrumu og setja kjarna úr líkamsfrumu sjúklings í eggfrumuna í staðinn. Pessi eggfruma yrði látin proskast í kímblöðrustig, par sem innri frumumassi yrði nýttur til sérhæfingar í tiltekna frumugerð sem væri nauðsynleg sjúklingnum. Hann myndi pví ekki hafna frumum sem innhalda hans eigið genamengi. Slík klónun í mönnum í læknisfræðilegum tilgangi tókst nýlega. ${ }^{25}$

Rannsóknir á fósturvísum eru leyfðar á Íslandi, samanber lög um tæknifrjóvganir, nr. 55 frá $2008^{26}$ og er pví unnt að einangra stofnfrumur úr fósturvísum manna hér á landi samkvæmt núgildandi lögum. Pess ber pó að geta að slíkar rannsóknir eru undir ströngu eftirliti Vísindasiðanefndar og einangrun stofnfrumna úr mönnum hefur ekki verið framkvæmd hér á landi enn sem komið er, enda dýrt ferli.

\section{Endurforritaðar frumur umturna kenningu um óafturkræfðar sérhæfðar frumur}

Nóbelsverðlaunin í lífeðlis- og læknisfræði árið 2012 skiptust á milli tveggja vísindamanna, John B. Gurdon, Cambridge-háskóla, Bretlandi og Shinya Yamanaka, Kyoto-háskóla, Japan. Verðlaunin voru veitt fyrir að sýna að proskaðar sérhæfðar frumur er hægt að endurforrita í fjölhæfar stofnfrumur. Niðurstöður peirra breyttu peirri almennu skoðun að sérhæfing líkamsfrumna (somatic cells) væri óafturkræf. ${ }^{27}$ Gurdon klónaði fyrstur manna frosk par sem hann flutti kjarna úr sérhæfðri líkamsfrumu úr froski í kjarnalaust egg, og sýndi fram á að erfðaupplýsingarnar úr líkamsfrumunni nægðu til að mynda halakörtu (1962). Yamanaka varð fyrstur til 


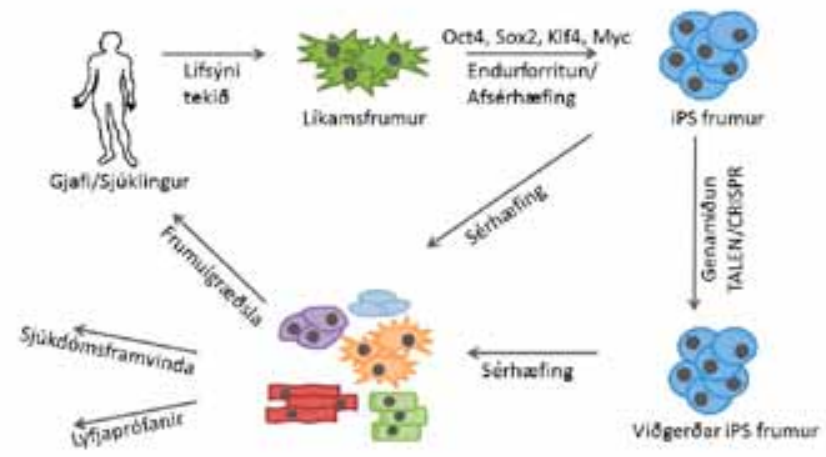

Mynd 2. iPS-frumur eru fjölhæfar stofnfrumur sem eru myndaðar með pví að endurforrita líkamsfrumur, og par með afsérhæfa pær. iPS-frumur hafa pann kost fram yfir stofnfrumur úr fósturvísum ( $h E S$-frumur) að pær hafa sama genamengi og líkamsfrumur pess einstaklings sem lífsýni hefur verið tekið úr. Dær eru pví mjög gagnleg uppspretta fyrir læknavísindin. Viðgerð á tilteknu geni sem orsakar sjúkdóm er möguleg i iPS-frumum sem síðan yrdu sérhæfðar í pá tilteknu frumugerð sem er óstarfhæfí sjúklingi og notaðar í ígræðslu. Einnig má nota iPS-frumur úr sjúklingum til að skilja betur sameindafræðilega ferla sjúkdómsins. Lyfjaprófanir eru pegar gerðar á iPS-frumum sjúklinga.

að umbreyta sérhæfðri líkamsfrumu beint í fjölhæfa stofnfrumu (2006). ${ }^{28}$

Í fósturproskun eru fyrstu frumurnar í fósturvísi ósérhæfðar en verða svo sérhæfðari með tímanum. Í kringum 1950 höfðu proskunarfræðingar klónað frosk með pví að flytja kjarna úr fósturvísi í kjarnalaust froskaegg (Rana pipiens) og myndaðist pá fullmynduð halakarta (Somatic Cell Nuclear Transfer, SCNT). ${ }^{29}$ Pegar peir reyndu á hinn bóginn að endurtaka svipaða tilraun með kjarnaflutningi úr sérhæfðri frumu í kjarnalaust froskaegg, mistókst fósturproskun í halakörtunni. ${ }^{30}$ Pví var almennt talið að erfðaupplýsingar í sérhæfðum frumum gangist undir óafturkræfar breytingar sem gera pað að verkum að frumurnar hafi takmarkaða sérhæfingarmöguleika. Pekkt myndlíking sem lýsti pessari viðteknu hugmynd vel var umframerfðalandslag (epigenetic landscape) Waddingtons sem sýndi kúlu uppi á fjallstoppi sem átti að líkjast ósérhæfðri stofnfrumu sem sérhæfðist meira og meira pví lengra sem hún rúllaði niður fjallið og endaði að lokum í dalverpi sem sérhæfð fruma. ${ }^{31}$ Niðurstöður John Gurdon breyttu pessari viðteknu skoðun manna. Hann notaði aðra froskategund (Xenopus laevis) í sínum rannsóknum. Honum tókst að flytja kjarna úr sérhæfðri líkamsfrumu frosksins (pekjufrumu meltingarvegarins) í kjarnalaust egg, og sýndi fram á að erfðaupplýsingarnar úr líkamsfrumunni nægðu til að mynda halakörtu, væru pær í réttu umhverfi. Petta gerði hann árið 1962. ${ }^{32}$ Með pessum niðurstöðum sýndi hann fram á að erfðaupplýsingar tapast ekki í sérhæfingarferlinu. Í dag vitum við að erfðaefnið er mistjáð í hinum mismunandi ósérhæfðu og sérhæfðu frumum. Gurdon breytti ekki aðeins grundvallarhugmyndum manna um óafturkræfni sérhæfðra frumna heldur innleiddi hann nýtt rannsóknarsvið og er stundum kallaður guðfaðir klónunar. ${ }^{33}$ Spurningunni hvort hægt væri að umbreyta líkamsfrumu einni og sér beint í fjölhæfa stofnfrumu var pó enn ósvarað. Yamanaka hafði í nokkur ár verið að skoða hvaða stjórnprótein/umritunarpættir halda ESfrumum ósérhæfðum og fjölhæfum og uppgötvaði meðal annars að NANOG-stjórnpróteinið verður að vera tjáð svo að ES-frumur haldist fjölhæfar. ${ }^{34}$ Peir Takahashi og Yamanaka framkvæmdu síðan djarfa tilraun par sem peir komu mismunandi samsetningum af stjórngenum fyrir í bandvefsfrumum músa í frumurækt með hjálp retróveirusýkingar og notuðu valkvætt próf til að rekja pær frumur sem umbreyttust í fjölhæfar stofnfrumur. Peim tókst að prengja hringinn niður í aðeins fjögur stjórngen: OCT4, SOX2, KLF4 og MYC (sem nú eru nefndir Yamanaka-pættirnir) er gátu endurforritað líkamsfrumurnar í fjölhæfar stofnfrumur (mynd 2). Frumur pessar höfðu eiginleika sem voru fyllilega sambærilegir við eiginleika ES-frumna. Pessar frumur fengu nafnið iPS-frumur (induced Pluripotent Stem cells). ${ }^{28}$ Ári seinna tókst sama rannsóknarhópi að mynda iPS-frumur úr mönnum. ${ }^{35}$ Á fáum árum hefur orðið bylting í rannsóknum á iPS-frumum. Ýmsar ólíkar aðferðir hafa verið prófaðar við að mynda iPS-frumur, bæði hvað varðar innskeytingaraðferðir á stjórngenunum, svo og frumugerð líkamsfrumnanna. Einnig hafa færri stjórnpættir verið prófaðir og kemur í ljós að sleppa má MYC, enda hefur hann valdið æxlismyndunum í músum sem á kímblöðrustigi hafa verið sprautaðar með iPS-frumum. Pegar retróveirugenaferjum með fjölhæfigenunum er skeytt inn í frumurnar innlimast pær tilviljanakennt inn í genamengið og gætu pví stuðlað að æxlismyndun. Pess vegna hefur verið reynt að komast hjá pví að nota retróveirugenaferjur, til dæmis með veirugenaferjum sem innlimast ekki, með stöðugu RNA og með próteinum. ${ }^{36,37}$ Heimtur á fjölhæfum iPS-frumum eru lágar og pví nauðsynlegt að nota valkvætt samrunagen til að velja úr pær frumur sem hafa endurforritast í iPS-frumur. Ferlið við að mynda iPS-frumur tekur um 2-3 vikur. En hvað gera Yamanakapættirnir til pess að ýta undir afsérhæfingu (de-differentiation)? Í stuttu máli virkja peir gen sem taka pátt í fjölhæfi frumna en pagga aftur á móti niður í genum sem hafa hlutverki að gegna í frumusérhæfingu. Áður var greint frá að EMT á sér stað í fósturproskun og við sérhæfingu hES-frumna. Yamanaka-pættirnir ýta par af leiðandi undir endurforritun með öfugu ferli sem nefnist Mesenchymal-to-Epithelial transition (MET). Sýnt hefur verið að SOX2/OCT4 halda niðri EMT-stjórnpróteininu SNAIL, KLF4 ýtir undir tjáningu á E-CADHERIN og C-MYC hindrar TGF- $\beta$ boðleiðina. ${ }^{38,39}$ I framhaldinu eykst tjáning á NANOG, SOX2 og OCT4 genum frumunnar og pessi aðalstjórnprótein fjölhæfis valda virkjun á peim genum sem nauðsynleg eru fjölhæfi, en virkja einnig svokölluð polycomb group prótein sem pagga niður tjáningu sérhæfingargena með litnisumbreytingu (chromatin remodelling)..$^{40}$

\section{Nytsemi fjölhæfra stofnfrumna}

Frá læknisfræðilegu sjónarhorni gætu iPS-frumur orðið gagnlegar í lyfjapróun og til skilnings á sjúkdómsferlum. Einnig væri hægt að hugsa sér að búa til sérhannaðar fjölhæfar stofnfrumur fyrir sjúklinga. Pessar frumur leysa nefnilega pann vanda að sjúklingur hafni ígræddum frumum enda hafa pær sama genamengi og sjúklingurinn sjálfur. Á seinustu árum hafa iPS-frumur verið búnar til úr afar mörgum sjúklingum og er aðgangur að upplýsingum par að lútandi opinn. ${ }^{41}$ 
iPS-frumur sjúklinga hafa verið sérhæfðar í pá frumugerð sem sjúklingur hefur óstarfhæfa í líkama sínum og lyfjapróf gerð á pessum frumum. Raunverulegt dæmi um pessa nálgun er sameindafræðileg rannsókn á iPS-frumum úr barni sem pjáðist af hjartsláttartruflunum. Unnt var að greina stökkbreytingu 1 SCN5A-geninu sem olli longQT-heilkenni í barninu. Lyfjaprófanir á iPS-ættuðum hjartavöðvafrumum gerðu pað að verkum að hægt var að meðhöndla barnið með réttum lyfjum. ${ }^{42}$ Lækning með iPS-frumum hefur sínar takmarkanir fyrir utan kostnaðarliðinn. I fyrsta lagi parf erfðapátturinn að vega pungt í sjúkdómnum eins og til dæmis í arfgenga slímseigjusjúkdómnum cystic fibrosis, sem orsakast fyrst og fremst af einni stökkbreytingu í CFTR-geninu. Pann sjúkdóm má pá rannsaka í lungnapekjufrumum. Á hinn bóginn væri erfitt að skoða sjúkdóma par sem margir erfða- og umhverfispættir spila saman. Í öðru lagi skipta viðmiðin öllu máli eins og í öðrum tilraunum. Pegar farið var að búa til iPSfrumur úr sjúklingum var notast við iPS-frumuviðmið úr heilbrigðum einstaklingum. Ólíkur erfðafræðilegur bakgrunnur í pessum frumum er mikið áhygguefni og gæti eins verið ástæða svipgerðarbreytinga í stað stökkbreytingarinnar sem verið er að rannsaka. Petta er talið vera brotalöm á pessum rannsóknum. ${ }^{43}$ Í priðja lagi er nauðsynlegt að iPS-frumur - bæði viðmið og pær sem hafa stökkbreytingu - séu búnar til á sama hátt, pað er með nákvæmlega sömu aðferð við sömu ræktunaraðstæður. Til viðbótar má nefna mögulega skekkju vegna mismunandi umframerfða pví pað hefur sýnt sig að iPS-frumur hafa mismunandi metýleringarmynstur. Pað getur haft áhrif á getu frumnanna til að sérhæfast í tiltekna frumugerð. Lausn á pessu viðmiðunarvandamáli er að nota fjölhæfar stofnfrumur sem hafa nákvæmlega sama erfðafræðilega bakgrunn utan stökkbreytingarinnar sem á að rannsaka, og mætti kalla pær samerfða (isogenic). Til pess að uppfylla slíkan gæðastaðal parf annars vegar að mynda iPS-frumur úr sjúklingi sem hefur ákveðna stökkbreytingu og búa svo til viðmiðunar-iPS-frumur með pví að leiðrétta sömu stökkbreytingu í sömu frumum. Аð öðrum kosti eru notaðar hES-frumur sem viðmið en stökkbreyting sem veldur sjúkdómnum yrði pá mynduð í sömu frumum og svipgerð síðan athuguð. Pessi nálgun er nú viðtekin og sem dæmi um slíkar aðferðir má annars vegar nefna athugun á LRRK2-stökkbreytingu sem talin er valda Parkinsonsjúkdómi ${ }^{4}$ og rannsókn á stökkbreytingu í KCNH2 sem veldur longQT-heilkenni. ${ }^{45}$ Í Japan hefur löggjöf verið rýmkuð til pess að gera kleift að græða iPS-afleiddar litpekjufrumur í sjúkling sem pjáist af vota forminu af aldursbundinni hrörnun í augnbotnum. Ekki er búist við að í pessari fyrstu aðgerð sinnar tegundar verði strax mögulegt að lækna hrörnunina heldur frekar að koma í veg fyrir enn meiri hrörnun og athuga hliðarverkanir, svo sem ónæmissvörun eða æxlisvöxt samfara aðgerðinni. ${ }^{46,47}$

Par sem ákveðin stökkbreyting í geni veldur sjúkdómnum pyrfti að leiðrétta stökkbreytinguna á iPS-frumustiginu með genamiðun (gene targeting) og sérhæfa frumurnar svo í kjölfarið í pá frumugerð sem sjúklingurinn parf á að halda (mynd 2). Samstæð litningaendurröðun (homologous recombination) er mjög vel pekkt og áhrifarík aðferð til að slá út gen í músum (,knockout-mýs“) en hún hefur reynst pung í vöfum við útslátt gena í hES-frumum og iPS-frumum. ${ }^{48}$ Á allra seinustu árum hafa miklar framfarir orðið í pessum geira. Transcription activator-like effector nucleases

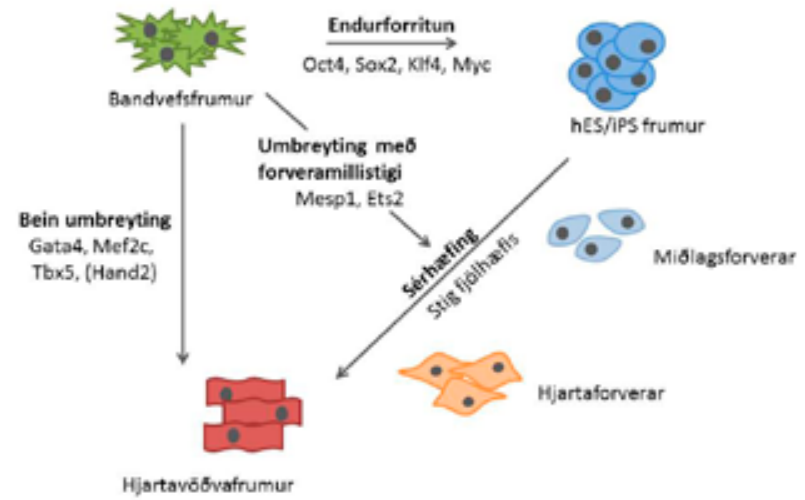

Mynd 3. Umbreyttar frumur. Unnt er að umbreyta líkamsfrumu beint i aðra líkamsfrumu án pess að endurforrita hana fyrst i fjölhæfa stofnfrumu. Fyrst tókst pessi umbreyting með forveramillistigi. Siððar tókst að umbreyta sérhæfðri frumu beint i aðra sérhæfða. Til dæmis er hægt að skeyta inn stjórngenunum GATA4, MEF2C, TBX5 og HAND2, sem eru hornsteinar hjartavöðvafrumna, og mynda pannig starfhxfar hjartavöðvafrumur.

(TALENs) eru ensím sem kljúfa tvípátta DNA á sértækum stöðum í genamenginu. Enn áhrifaríkari aðferð er CRISPR (Clustered regularly interspaced short palindromic repeats) tækni sem er ný aðferð sem leyfir breytingar á erfðaefni frumna og lífvera. Pessi tækni býður upp á afkastamikla aðferð í erfðatækni sem mætti nefna genaskurðlækningar. Nýlega eru nokkur dæmi pess að CRISPRtæknin hafi verið notuð til að leiðrétta stökkbreyttar iPS-frumur úr sjúklingum, svo sem Duchenne-vöðvarýrnunarsjúkdóminn. ${ }^{49}$ Ýmsar framfarir hafa pegar orðið á pessari nýju tækni til pess að forðast „off-target“ áhrif og má gera ráð fyrir að aðferðin verði próuð enn frekar á næstu árum..$^{50-52}$

\section{Stytt leiô - Líkamsfrumum umbreytt beint i aơrar líkamsfrumur}

Lengi hefur verið vitað að stjórnpróteinið MYOD1 stjórnar tjáningu gena sem hafa hlutverki að gegna í proskun beinagrindavöðva. Ef pessu geni er skeytt í bandvefsfrumur pá virkjast vöðvaproskunargen og frumurnar umbreytast í beinagrindavöðvafrumur. ${ }^{53}$ iPS-frumurnar ollu straumhvörfum í stofnfrumurannsóknum og í framhaldi af pessum mikla áfanga hafa vísindamenn prófað sig áfram með að umbreyta líkamsfrumum jafnvel beint í aðrar líkamsfrumur án milligöngu hinna fjölhæfu iPS-frumna (direct reprogramming). Ein af fyrstu tilraununum var gerð á rannsóknarstofu í sykursýki, par sem briskirtilsfrumur voru endurforritaðar í insúlín-myndandi beta-frumur í músum in vivo. Níu genum sem eru pýðingarmikil í beta-frumuproskun var skeytt inn í bris músar í mismunandi samsetningum. Í ljós kom að samsetning priggja gena, sem eru umritunarpættirnirnir NGN3, PDX1 og MAFA, var nægileg og nauðsynleg til pess að stuðla að umbreytingu briskirtilsfrumna í beta-eyju-frumur (20\% heimtur). ${ }^{54}$ Pess má pó geta að báðar pessar frumugerðir eru afkomendur sama forverans og pví um færri utanerfðapætti að ræða heldur en við umbreytingu frumugerðar í aðra frumugerð sem jafnvel á uppruna í öðru fósturlagi. Í kjölfarið hefur mýmörgum frumum verið umbreytt. Vegna pess hversu algengt pað er að hjarta- og æða- 
sjúkdómar dragi fólk til dauða er mikilvægt að geta endurmyndað hjartavöðvafrumur. Fyrst tókst að umbreyta bandvefsfrumum í hjartavöðvafrumur með pví að af-sérhæfa pær í átt að fjölhæfi en stöðva á ákveðnu millistigi (pluripotent intermediate) og sérhæfa pær pá í skilyrtu æti í hjartaforvera (mynd 3). Petta hefur einnig verið gert með stjórnpróteinunum MESP1 og ETS2. ${ }^{55,56}$ Nú hefur tekist að umbreyta bandvefsfrumum beint í hjartavöðvafrumur in vitro með innskeytingu stjórnpróteinanna GATA4, MEF2C, TBX557 og HAND2. ${ }^{58}$ Hjartadrep var framkallað í músum og stjórnpróteinum komið inn í bandvefsfrumur í skiptingu í örvefnum með hjálp retróveira en pær sýkja ekki hjartavöðvafrumur pví pær eru ekki í skiptingu. Í tilraunum pessum var virkni hjartans bætt með hjálp umbreyttra bandvefsfrumna í starfhæfar hjartavöðvafrumur. Pótt hér hafi aðeins verið tekið dæmi um hjartavöðvafrumur hefur ýmsum líkamsfrumum (pó einkum bandvefsfrumum) verið umbreytt beint yfir í ýmsar frumugerðir.

\section{Samantekt}

Í kjölfarið á fyrstu einangrun stofnfrumna úr fósturvísum manna (hES-frumum) árið 1998 urðu ótrúlegar framfarir í rannsóknum á pessum fjölhæfum stofnfrumum. Skilningur á sameindafræðilegum ferlum í fjölhæfum frumum jókst til muna og leiddi til pess að líkamsfrumur voru endurforritaðar í fjölhæfar stofnfrumur sem nefndar eru iPS-frumur og höfðu mjög svipaða eiginleika og hES-frumur. Pessi áfangi gjörbylti einnig hugmyndum fólks um óafturkræfi frumuproska pví niðurstöður tilraunarinnar sönnuðu að afsérhæfa mætti sérhæfðar frumur. Í framhaldinu hefur einnig tekist að umbreyta sérhæfðri frumu beint í aðra sérhæfða frumu af allt öðrum toga án fjölhæfa millistigsins. Miklar vonir eru bundnar við nytsemi fjölhæfra stofnfrumna í læknavísindum, pað er í lyfjaprófunum og vefjaígræðslum. Nú pegar hafa verið framkvæmdar lyfjaprófanir á iPS-afleiddum frumum sjúklinga og pær gefið góða raun. Mikið kapp er lagt á að bæta aðferðir til pess að leiðrétta stökkbreytingar í iPS-frumum sjúklinga svo að hægt sé að græða iPS-afleiddar frumur aftur í sjúklinginn. Ýmsar hindranir eru á veginum, svo sem heimtur ígræddra frumna í skaddaðan vef sjúklings, auk pess sem slík einstaklingsbundin lækning yrði mjög kostnaðarsöm.

\section{Pakkir}

Ég vil pakka Eiríki Steingrímssyni og Ásdísi Kristjánsdóttur fyrir yfirlestur handrits og góðar ábendingar. Einnig vil ég pakka Ernu Magnúsdóttur fyrir gagnlegar samræður.

\section{Heimildir}

1. Pera MF, Trounson AO. Human embryonic stem cells: prospects for development. Development 2004; 131: 5515 -

2. Guðjónsson T, Steingrimsson E. Eiginleikar stofnfrumna: frumusérhæfing og ný meðferðarúrræði? Læknablaðið 2003; 89: 43-8.

3. Drukker M, Katz G, Urbach A, Schuldiner M, Markel G, Itskovitz-Eldor J, et al. Characterization of the expression of MHC proteins in human embryonic stem cells. Proc Natl Acad Sci U S A 2002; 99: 9864-9.

4. Eastham AM, Spencer H, Soncin F, Ritson S, Merry CL Stern PL, et al. Epithelial-mesenchymal transition events during human embryonic stem cell differentiation. Cancer Res 2007; 67: 11254-62.

5. Richter A, Valdimarsdottir L, Hrafnkelsdottir HE, Runarsson JF, Omarsdottir AR, Ward-van Oostwaard D, et al. BMP4 promotes EMT and mesodermal commitment in human embryonic stem cells via SLUG and MSX2. Stem Cells 2014; 32: 636-48

6. Tan EJ, Olsson AK, Moustakas A. Reprogramming during epithelial to mesenchymal transition under the control of TGFbeta. Cell Adh Migr 2015; 9: 233-46.

7. Evans MJ, Kaufman MH. Establishment in culture of pluripotential cells from mouse embryos. Nature 1981; 292: 154-6.

8. Martin GR. Isolation of a pluripotent cell line from early mouse embryos cultured in medium conditioned by teratocarcinoma stem cells. Proc Natl Acad Sci U S A 1981; 78: 7634-8.

9. Thomson JA, Kalishman J, Golos TG, Durning M, Harris $\mathrm{CP}$, Becker RA, et al. Isolation of a primate embryonic stem cell line. Proc Natl Acad Sci U S A 1995; 92: 7844-8.

10. Thomson JA, Itskovitz-Eldor J, Shapiro SS, Waknitz MA Swiergiel JJ, Marshall VS, et al. Embryonic stem cell lines derived from human blastocysts. Science 1998; 282: 1145-7.

11. Xu RH, Peck RM, Li DS, Feng $X$, Ludwig T, Thomson JA. Basic FGF and suppression of BMP signaling sustain undifferentiated proliferation of human ES cells. Nat Methods 2005; 2: 185-90.

12. Amit M, Itskovitz-Eldor J. Maintenance of human embryonic stem cells in animal serum- and feeder layerfree culture conditions. Methods Mol Biol 2006; 331: 10513.
13. Xu RH, Sampsell-Barron TL, Gu F, Root S, Peck RM, Pan $\mathrm{G}$, et al. NANOG is a direct target of TGFbeta/activinmediated SMAD signaling in human ESCs. Cell Stem Cell 2008; 3: 196-206.

14. Chambers I, Colby D, Robertson M, Nichols J, Lee S, Tweedie S, et al. Functional expression cloning of Nanog, a pluripotency sustaining factor in embryonic stem cells. Cell 2003; 113: 643-55.

15. Young RA. Control of the embryonic stem cell state. Cell 2011; 144: 940-54.

16. Jaenisch R, Young R. Stem cells, the molecular circuitry of pluripotency and nuclear reprogramming. Cell 2008; 132: 567-82.

17. Amit M, Itskovitz-Eldor J. Derivation and spontaneous differentiation of human embryonic stem cells. J Anat 2002; 200: 225-32.

18. Kriks S, Shim JW, Piao J, Ganat YM, Wakeman DR, Xie $Z$, et al. Dopamine neurons derived from human ES cells efficiently engraft in animal models of Parkinson's disease. Nature 2011; 480: 547-51.

19. Reubinoff $B E$, Itsykson $\mathrm{P}$, Turetsky $\mathrm{T}$, Pera MF, Reinhartz E, Itzik A, et al. Neural progenitors from human embryonic stem cells. Nat Biotechnol 2001; 19: 1134-40.

20. Kirkeby A, Grealish S, Wolf DA, Nelander J, Wood J, Lundblad $\mathrm{M}$, et al. Generation of regionally specified neural progenitors and functional neurons from human embryonic stem cells under defined conditions. Cell Rep 2012; 1: 703-14.

21. Yang L, Soonpaa MH, Adler ED, Roepke TK, Kattman SJ, Kennedy M, et al. Human cardiovascular progenitor cells develop from a KDR+ embryonic-stem-cell-derived population. Nature 2008; 453: 524-8.

22. Laflamme MA, Chen KY, Naumova AV, Muskheli V, Fugate JA, Dupras SK, et al. Cardiomyocytes derived from human embryonic stem cells in pro-survival factors enhance function of infarcted rat hearts. Nat Biotechnol 2007; 25: 1015-24

23. Kehat I, Khimovich L, Caspi O, Gepstein A, Shofti R, Arbel $\mathrm{G}$, et al. Electromechanical integration of cardiomyocytes derived from human embryonic stem cells. Nat Biotechnol 2004; 22: 1282-9.

24. Van Laake LW, Van Hoof D, Mummery CL. Cardiomyocytes derived from stem cells. Ann Med 2005; 37: 499-512.
25. Tachibana M, Amato P, Sparman M, Gutierrez NM, Tippner-Hedges R, Ma H, et al. Human embryonic stem cells derived by somatic cell nuclear transfer. Cell 2013; 153: 1228-38.

26. Lög um tæknifrjóvgun og notkun kynfrumna og fósturvísa manna til stofnfrumurannsókna. Lagasafn. Íslensk lög 1. október 2009.

27. Rossant J, Mummery C. NOBEL 2012 Physiology or medicine: Mature cells can be rejuvenated. Nature 2012; 492: 56.

28. Takahashi K, Yamanaka S. Induction of pluripotent stem cells from mouse embryonic and adult fibroblast cultures by defined factors. Cell 2006; 126: 663-76.

29. Briggs R, King TJ. Transplantation of Living Nuclei From Blastula Cells into Enucleated Frogs' Eggs. Proc Natl Acad Sci U S A 1952; 38: 455-63.

30. King TJ, Briggs R. Changes in the Nuclei of Differentiating Gastrula Cells, as Demonstrated by Nuclear Transplantation. Proc Natl Acad Sci U S A 1955; 41: 321-5.

31. Waddington $\mathrm{CH}$. The strategy of the gene. A discussion of some aspects of theoretical biology. Allen and Unwin Ltd, London 1957.

32. Gurdon JB. The developmental capacity of nuclei taken from intestinal epithelium cells of feeding tadpoles. J Embryol Exp Morphol 1962; 10: 622-40.

33. Kolata G. Clone: The Road To Dolly, And The Path Ahead. William Morrow and Company Inc, New York 1998.

34. Mitsui K, Tokuzawa Y, Itoh H, Segawa K, Murakami M, Takahashi K, et al. The homeoprotein Nanog is required for maintenance of pluripotency in mouse epiblast and ES cells. Cell 2003; 113: 631-42.

35. Takahashi K, Tanabe K, Ohnuki M, Narita M, Ichisaka T, Tomoda K, et al. Induction of pluripotent stem cells from adult human fibroblasts by defined factors. Cell 2007; 131: $861-72$

36. Gonzalez F, Boue S, Izpisua Belmonte JC. Methods for making induced pluripotent stem cells: reprogramming a la carte. Nat Rev Genet 2011; 12: 231-42.

37. Chun YS, Byun K, Lee B. Induced pluripotent stem cells and personalized medicine: current progress and future perspectives. Anat Cell Biol 2011; 44: 245-55. 
38. Li R, Liang J, Ni S, Zhou T, Qing X, Li H, et al. A mesenchymal-to-epithelial transition initiates and is required for the nuclear reprogramming of mouse fibroblasts. Cell Stem Cell 2010; 7: 51-63.

39. Samavarchi-Tehrani P, Golipour A, David L, Sung HK, Beyer TA, Datti A, et al. Functional genomics reveals a BMP-driven mesenchymal-to-epithelial transition in the initiation of somatic cell reprogramming. Cell Stem Cell 2010; 7: 64-77.

40. Polo JM, Hochedlinger K. When fibroblasts MET iPSCs. Cell Stem Cell 2010; 7: 5-6.

41. Santostefano KE, Hamazaki T, Biel NM, Jin S, Umezawa A, Terada N. A practical guide to induced pluripotent stem cell research using patient samples. Lab Invest 2015; 95 $4-13$.

42. Terrenoire C, Wang K, Tung KW, Chung WK, Pass RH, $\mathrm{Lu} \mathrm{JT}$, et al. Induced pluripotent stem cells used to reveal drug actions in a long QT syndrome family with complex genetics. J Gen Physiol 2013; 141: 61-72.

43. Musunuru K. Personalized genomes and cardiovascular disease. Cold Spring Harb Perspect Med 2015; 5: a014068.

44. Reinhardt P, Schmid B, Burbulla LF, Schondorf DC Wagner L, Glatza M, et al. Genetic correction of a LRRK2 mutation in human iPSCs links parkinsonian neurodegeneration to ERK-dependent changes in gene expression. Cell Stem Cell 2013; 12: 354-67.

45. Bellin M, Casini S, Davis RP, D'Aniello C, Haas J, Wardvan Oostwaard D, et al. Isogenic human pluripotent stem cell pairs reveal the role of a KCNH2 mutation in long-QT syndrome. Embo J 2013; 32: 3161-75.
46. Cyranoski D. Japanese woman is first recipient of nextgeneration stem cells 2014. 15.03.2015; nature.com/news/ japanese-woman-is-first-recipient-of-next-generationstem-cells-1.15915 - apríl 2015.

47. Pilot safety study of iPSC-based intervention for wettype AMD 2013. 12.03.2015; riken-ibri.jp/AMD/english/ research/index.html - apríl 2015.

48. Moretti A, Laugwitz KL, Dorn T, Sinnecker D, Mummery C. Pluripotent stem cell models of human heart disease. Cold Spring Harb Perspect Med 2013; 3: 49.

49. Li HL, Fujimoto N, Sasakawa N, Shirai S, Ohkame T, Sakuma T, et al. Precise Correction of the Dystrophin Gene in Duchenne Muscular Dystrophy Patient Induced Pluripotent Stem Cells by TALEN and CRISPR-Cas9. Stem Cell Reports 2015; 4: 143-54.

50. Fu Y, Sander JD, Reyon D, Cascio VM, Joung JK. Improving CRISPR-Cas nuclease specificity using truncated guide RNAs. Nat Biotechnol 2014; 32: 279-84.

51. Ran FA, Hsu PD, Wright J, Agarwala V, Scott DA, Zhang F. Genome engineering using the CRISPR-Cas 9 system. Nat Protoc 2013; 8: 2281-308.

52. Tsai SQ, Wyvekens N, Khayter C, Foden JA, Thapar V, Reyon D, et al. Dimeric CRISPR RNA-guided FokI nucleases for highly specific genome editing. Nat Biotechnol 2014; 32: 569-76.

53. Davis RL, Weintraub H, Lassar AB. Expression of a single transfected cDNA converts fibroblasts to myoblasts. Cell 1987; 51: 987-1000.
54. Zhou Q, Brown J, Kanarek A, Rajagopal J, Melton DA. In vivo reprogramming of adult pancreatic exocrine cells to beta-cells. Nature 2008; 455: 627-32.

55. Islas JF, Liu Y, Weng KC, Robertson MJ, Zhang S, Prejusa A, et al. Transcription factors ETS2 and MESP1 transdifferentiate human dermal fibroblasts into cardiac progenitors. Proc Natl Acad Sci U S A 2012; 109: 13016-21.

56. Efe JA, Hilcove S, Kim J, Zhou H, Ouyang K, Wang G, et al. Conversion of mouse fibroblasts into cardiomyocytes using a direct reprogramming strategy. Nat Cell Biol 2011; 13: $215-22$.

57. Qian L, Huang Y, Spencer CI, Foley A, Vedantham V, Liu $\mathrm{L}$, et al. In vivo reprogramming of murine cardiac fibroblasts into induced cardiomyocytes. Nature 2012; 485: 593-8.

58. Song K, Nam YJ, Luo X, Qi X, Tan W, Huang GN, et al. Heart repair by reprogramming non-myocytes with cardiac transcription factors. Nature 2012; 485: 599-604.

ENGLISH SUMMARY

\section{Breakthrough in research on pluripotent stem cells and their application in medicine}

Guðrún Valdimarsdóttir, Anne Richter

Embryonic stem cells are, as the name indicates, isolated from embryos. They are pluripotent cells which can be maintained undifferentiated or induced to differentiate into any cell type of the body. In 1998 the first isolation of human embryonic stem cells was successful and they became an interesting source for stem cell regenerative medicine. Only 8 years later pluripotent stem cells were generated by reprogramming somatic cells into induced pluripotent stem cells (iPSCs). This was a revolution in the way people thought of cell commitment during development. Since then, a lot of research has been done in understanding the molecular biology of pluripotent stem cells. iPSCs can be generated from somatic cells of a patient and therefore have the same genome. Hence, iPSCs have great potential application in medicine, as they can be utilized in disease modelling, drug screening and cell replacement therapy.

Dept. Biochemistry and Molecular Biology, Faculty of Medicine, BMC, University of Iceland

Key words: pluripotent stem cells, differentiation, reprogramming, iPSCs, direct lineage reprogramming.

Correspondence: Guđrún Valdimarsdóttir gudrunva@hi.is 